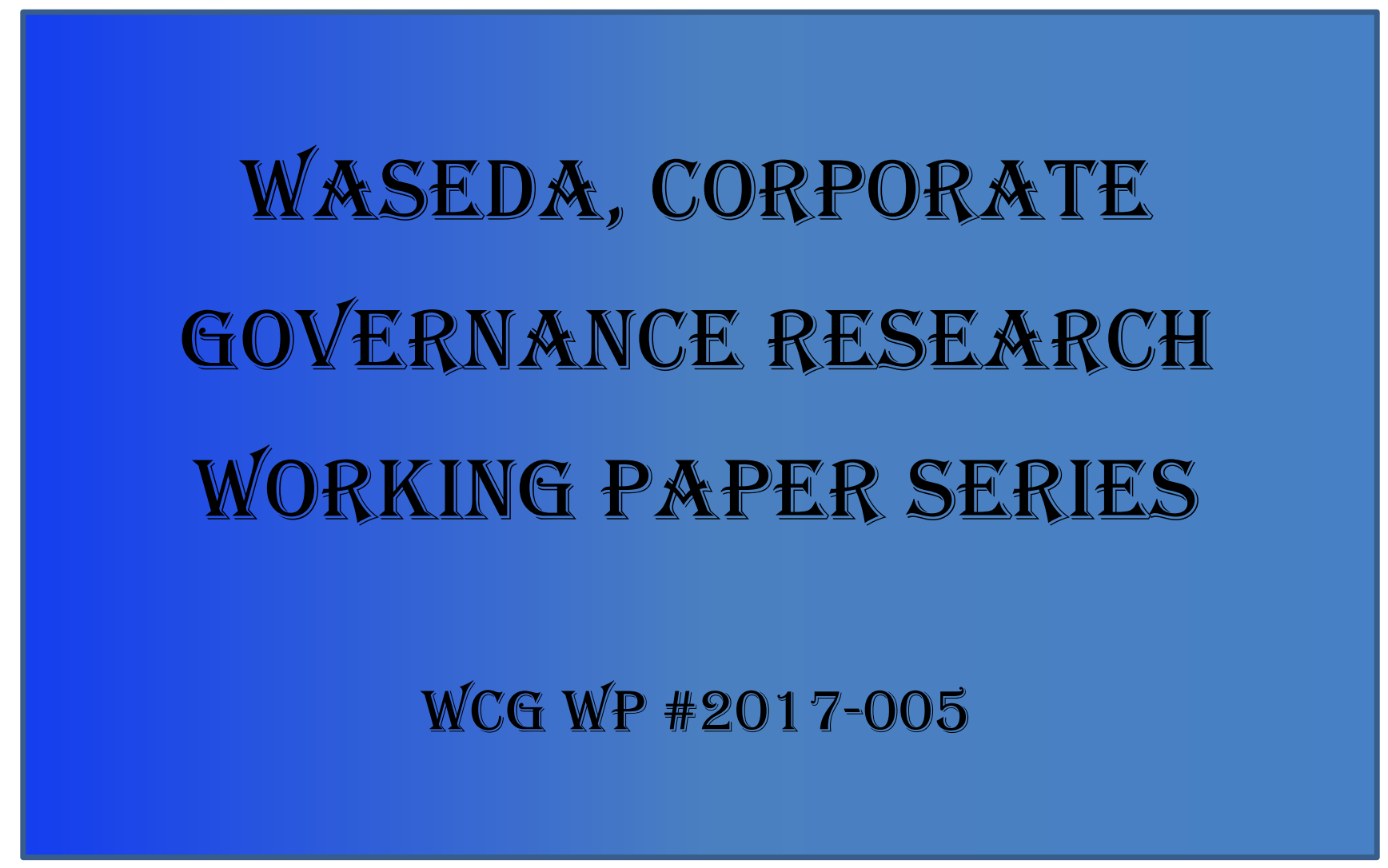

Are Japanese companies less risky and less profitable than U.S. companies?

-- Evidence from a matched sample

\author{
Jiangtao $\mathrm{Fu}$ (Waseda University) \\ Yoshiaki Ogura (Waseda University)
}

JSPS Core-to-Core Program

Waseda Institute for Advanced Studies 


\section{ABOUT JSPS CORE-TO-CORE PROGRAM}

This work was supported by "Core-to-Core Program, A. Advanced Research Networks" of Japan Society for the Promotion of Science (JSPS).

The main objectives of "Core-to-Core Program" are to create world-class research hubs in the research fields, and to foster young researchers through building sustainable collaborative relations among research/education institutions in Japan and around the world.

As a research hub in Japan for the project titled "Creation of a Research Hub for Empirical Analysis on the Evolving Diversity of Corporate Governance: Multidisciplinary Approach Combining Economics, Legal Studies and Political Science" which was selected for "Core-to-Core Program", Waseda Institute for Advanced Studies (WIAS) works together with its overseas counterparts: University of Oxford (UK), Ecole des Hautes Etudes en Sciences Sociales (EHESS) (France), University of British Columbia (UBC) (Canada). Through strengthening the research networks, developing analysis methods, adopting a multifaceted international approach and promoting the joint use of basic data, this project aims to achieve remarkable advancements in empirical analysis of the economic systems associated with corporate governance. 


\title{
Are Japanese companies less risky and less profitable than U.S. companies? -- Evidence from a matched sample ${ }^{\dagger}$
}

\author{
Jiangtao $\mathrm{Fu}^{\mathrm{a}}$ \\ Graduate School of Economics, Waseda University \\ Yoshiaki Ogura ${ }^{\mathrm{b}}$ \\ School of Political Science and Economics, Waseda University
}

\begin{abstract}
We reexamine the difference between the U.S. and Japan in the profitability distribution of listed companies. To control for the cross-country differences in the industrial composition, firm size and firm age distribution, we constructed a matched sample by the Mahalanobis nearest neighborhood matching with respect to these factors. The matched sample supports the finding in the extant studies that the median and the standard deviation of the profitability are significantly higher in the U.S. than in Japan. Our matched panel data also indicate that this difference comes from both larger firm heterogeneity and the more intensive risk-taking in the U.S.

JEL Classification: G32, G38, L25

Keyword: risk-taking, allocative efficiency, firm heterogeneity

\footnotetext{
$\dagger$ We thank Yasuhiro Arikawa, Shin'ichi Hirota, Hideaki Miyajima, and Xueping Wu, and the participants at the JSPS Core-to-Core Program workshop (INCAS- $1^{\text {st }}$ Workshop) at EHESS, Paris, June 2015, for insightful comments. We gratefully acknowledge the research assistance by Yue Cai. This study is financially supported by JSPS KAKENHI Grant Number JP15H01958.

a Address: 1-6-1 Nishi Waseda, Shinjuku-ku, Tokyo, 169-8050, Japan. E-mail: jetafull@gmail.com.

${ }^{b}$ Address: 1-6-1 Nishi Waseda, Shinjuku-ku, Tokyo, 169-8050, Japan. E-mail: yogura@waseda.jp.
} 


\section{Introduction}

Recent international comparisons of the profitability of large companies show that the median and the standard deviation of the profitability, which is measured by ROA, ROE, or the return on sales, of Japanese companies is significantly lower than that of other major countries (John et al 2008; Ministry of Economy, Trade, and Industry 2014; Arikawa et al 2016). This finding provokes a policy debate about the cause of the low-risk and low-return of Japanese companies. The most influential argument is that the relatively weaker legal protection for the shareholders' right and the relatively stronger protection for employees prevent Japanese companies from taking risks that can make them grow faster. However, a rigorous examination for the argument that Japanese companies are less risky and less profitable has not yet been fully conducted. For example, the industrial composition varies significantly by countries. The distributions of firm size and firm age are also different by countries due to the gap in the level of the stock market development (Brown and Kapadia 2007). Besides, it is not still clear enough which component of the standard deviation, either firm heterogeneity or idiosyncratic factor, is the primary cause of the cross-country difference. The former is more related to the innovation that brings a productivity gap among companies, while the latter is more related to risk-taking by each company. Our purpose of this research note is to provide a more rigorously stylized fact about the cross-country comparison of profitability distributions after controlling for the industrial composition and the distribution of size and age.

To this end, we compare the profitability distributions between the U.S. and Japan by a matched sample in each year from 2005 to 2014, which is constructed by the Mahalanobis nearest neighborhood matching with respect to industrial sector, firm size, and age. We also construct a 
panel data of the matched sample, and calculate the risk-taking index proposed by John et al (2008) for each company with this matching sample, and conduct a cross-country comparison of it.

The comparison shows that the median and the standard deviation of ROA and the operating cash flow over total asset of the U.S. firms is still significantly larger than that of Japanese firms in this matched sample although the difference is smaller than the unmatched sample. The decomposition of the variation by a random-effect model for the matched panel data shows that both the firm heterogeneity and the idiosyncratic variation are larger in the U.S. The firm-level risk-taking index by John et al (2008) in the matched panel sample is also larger in the U.S. than in Japan. Thus, our comparison by the matched sample supports the observation that the U.S. listed firms exhibit wider heterogeneity and take more risks than Japanese companies and that the median return for the U.S. companies is larger than that for Japanese.

The remaining part of this paper is organized as follows. We describe our data source and the sample selection in Section 2. We present the preliminary comparison of profitability by the row sample before matching in Section 3. We present the various profitability comparison and the decomposition of variation with the matched sample in Section 4. Section 5 is the conclusion.

\section{Data}

\section{$2.1 \quad$ Source}

Our data is collected from OSIRIS, Bureau van Dijk. The database provides a financial statement information of listed companies. The items are aggregated up to the level where users can conduct a reasonable international comparison. We collect the financial statement data and other basic characteristics from 2005 to 2014 of non-financial and non-utility companies whose 
headquarters are located in the U.S. or Japan. We focus on those companies that are listed on a regular stock exchange. In addition to OSIRIS, we obtain the name of the session and the stock exchange, where each company is listed at the end of December in each year, from Bureau van Dijk. The regular stock exchanges in the U.S. includes all sessions in New York Stock Exchange, including the former American Stock Exchange, and NASDAQ. Those in Japan include the first and the second sections and the sections for small capital companies in Tokyo Stock Exchange, Osaka Stock Exchange, ${ }^{1}$ Nagoya Stock Exchange, Fukuoka Stock Exchange, Sapporo Stock Exchange, and JASDAQ. OSIRIS contains U.S. companies that are traded on the OTC Bulletin Board, but we drop these firms from our analysis since they are much smaller and more volatile than those listed on the above regular exchanges. The items in the balance sheet and the income statement are denominated in the current U.S. dollar at the end of each accounting period. We keep using the two-digit classification in the North American Industry Classification System in 2012 (NAICS 2012) after aggregating several classifications ${ }^{2}$ as an industry classification code throughout our analysis.

\subsection{Measures of profitability}

We focus on two measures of profitability. One is ROA, defined by the ratio of EBITDA (earnings before interests, tax, depreciation and amortization) over total asset. EBITDA is directly available from OSIRIS. We focus on ROA rather than the return on equity, since the former is less susceptible to the manipulation of the capital structure. The other one is the ratio of the net cash flow from operating activities over total asset. We download the net cashflow from operating

1 The spot market for stocks at the Osaka Stock Exchange was consolidated into the Tokyo Stock Exchange on July 16, 2013.

2 Sectors 31-33 are classified as manufacturing. Likewise, Sectors 44-45 are classified as retail trade, and Sectors 48-49 are classified as transportation and warehousing. 
activities directly from OSIRIS, too. The benefit of using cash flow is that we can avoid the noise resulting from various accruals and the room for manipulations.

3 Comparison by the row data

\subsection{Industry composition}

Table 1 shows the industrial composition of listed companies in these countries at three data points, 2006, 2010, and 2014. The manufacturing sector accounts for the largest share, about a half, in both countries. The share, however, is declining in both countries. The notable difference is that the share of the mining sector is much larger in the U.S. than in Japan. The U.S. has several major companies in oil extractions and other natural resources, including relatively newly developed sectors like shale oil/gas extractors, whereas Japan has very few of such companies. It is reasonable to suspect that the larger presence of this sector in the U.S. pushes up the higher return and the higher risk of the aggregate U.S. industry since the mining sector is exposed to the higher volatility of commodity prices. Another difference is that the share of the construction sector is considerably larger in Japan than in the U.S.

\subsection{Firm characteristics}

Table 2 is the summary statistics of the firm characteristics in each country in 2006, 2010, and 2014. The mean asset and the mean book-value equity of Japanese companies in our sample are smaller than those of the U.S. companies by half. This is probably because we drop U.S. companies listed on the OTC Bulletin Board. In contrast, the firm age, i.e., the number of years since incorporation of Japanese companies are larger than that of U.S. companies by twice. We do not 
find any clear difference in the leverage, which is defined by the ratio of the total liability over the total asset.

\subsection{Comparison of the profitability distribution}

Table 2 shows the Japan-US comparison of the profitability, i.e., ROA, and the ratio of operating cash flow over asset. The stark difference between Japan and U.S. is found in the median and the standard deviation. U.S. firms are significantly higher than Japanese firms in terms of them, whereas the difference in means is not clear. This implies that the profitability of U.S. firms is more volatile in time-series and/or cross-section terms than Japanese firms. More than half of U.S. firms earn more than the median Japanese firm. However, a few extremely loss-making firms drag down the average in the U.S.

Figure 1 clearly shows that the median and the standard deviation is much higher in the U.S. than in Japan in both profitability measures. We can obtain clear statistical evidence on these features. The median profitability of U.S. firms is higher than that of Japanese ones in every sample years at a statistical significance level of $1 \%$, in both profitability measures (Column 2 in Table 3 ). The standard deviation in the U.S. is also significantly higher than that in Japan in every year (Colum 3 in Table 3).

4 Comparison by the matched data

\subsection{Concern on the sample selection for comparison}

An obvious concern in the above simple comparison is whether we really compare the groups of firms with similar traits. As we have already shown, the industrial composition in the U.S. and 
Japan is different with each other. The larger share of the mining and oil extraction sector in the U.S. might pushes up the median and the volatility of the profitability. The fact that U.S. listed firms are younger, due to the highly developed stock market, might drives up the volatility of the U.S. even more (Brown and Kapadia 2007), while the fact that the asset size is larger in the U.S. might push down the volatility of the U.S. firms. To mitigate these concerns, we construct a matched-sample dataset by applying the Mahalanobis nearest neighborhood matching, so that we can compare the groups of firms with a similar size and age in the same industrial sector.

\subsection{Matching method}

For each Japanese listed company, we assign a matched US listed firm with the nearest Mahalanobis distance in the same industrial classification by allowing a US firm to be chosen multiple times. In our context, the Mahalanobis distance between firm A in Japan and firm B in the U.S. with respect to $n$ characteristics is defined by

$$
\sqrt{(x-y)^{T} S^{-1}(x-y)}
$$

where $x(\mathrm{n} \times 1)$ is the vector of characteristics of firm A and $\mathrm{y}(n \times 1)$ is that of firm $\mathrm{B}, S$ is the sample variance-covariance matrix $(n \times n)$ among these characteristics, which is calculated with the full sample combining both countries (Abadie et al 2004). ${ }^{3} \quad$ We do not set a caliper limit to maintain the sample size as large as possible. We choose two characteristics for defining the distance: firm age and book-value equity. We impose the exact matching with respect to our industrial classification based on NAICS2012 two digit.

Another possible way to construct a matched sample is to find the nearest-neighbor Japanese firm

3 We use the STATA command, teffects nnmatch, for this purpose. 
for each U.S. firms. However, we do not take this way since it is often hard to find a reasonable nearest-neighbor for several U.S. companies that are too far away from any Japanese companies, given the much wider variety in U.S. companies.

In the matched sample, the industrial composition is closer to that of Japanese companies due to our choice of the matching method (Table 4). The density function of firm age and equity size gets significantly closer by the matching (Figure 2). Figure 2 shows the density in 2010 only, but the figures in the other years looks alike. Thus, we can control for the differences in the industrial composition, firm size, and firm age reasonably well by the nearest neighborhood matching.

\subsection{Comparison of the profitability distribution}

The cross-country difference in the mean of ROA and the operating cashflow over asset is smaller and negligible in the matched sample ((1) in Panels (a) and (b), Figure 3). The median and the standard deviation is significantly higher in the U.S. although the difference is reasonably smaller than in the unmatched sample ((2) and (3) in Panels (a) and (b), Figure 3). The median of ROA is around $12 \%$ in the U.S., while it is around $8 \%$ in Japan. The median of the operating cashflow over total asset is about $8 \%$ in the U.S., while it is around 6\% in Japan. The difference in the median temporarily dropped in 2009 and that in the standard deviation temporarily increased in the same year since the global financial crisis hit more severely and directly a part of the U.S. companies. These points are verified by statistical tests for the difference in these descriptive statistics (Table 5). The estimated kernel density functions of the matched sample in the years of 2006, 2010, and 2014 are depicted in Figure 4. ${ }^{4}$ The density function in the U.S. is located on the right of the Japanese density,

\footnotetext{
${ }^{4}$ In addition, we tested the first-order stochastic dominance, and the second-order stochastic dominance with the matched sample and the unmatched sample by the method of Davidson and Duclos (2000).
} 
and the former is flatter than the latter, i.e., the median and the standard deviation is consistently higher in the U.S. than in Japan.

Thus, our analysis gives compelling evidence for the finding that the median and the standard deviation in profitability is larger in the U.S. than in Japan, not simply because of the difference in the industry composition, firm age, or firm capital size, but for other reasons.

\subsection{Source of the difference in the volatility}

\subsubsection{Risk taking}

A possible explanation for this remaining difference in the standard deviation of the profitability is the difference in the extent of risk-taking between these countries. The existing studies show that Japanese companies tend to give priority to the stable employment than the higher return for shareholders since most of their board members are inside ones, such as former employees (Hirota 2014). Banks also exert the governance grip especially when a firm is under-capitalized and closer to default (Arikawa and Miyajima 2007), although the grip has weakened in the 2000s (Arikawa et al 2017). On the other hand, the shareholders' governance grip has been weaker relative to that in the U.S. for several reasons, including the typical structure of board members in Japanese companies, which I mentioned before. The key observation is that employees and banks are more risk-averse than shareholders, and more interested in the solvency and the survival of their company than the growth of it in the logic similar to the risk-shifting effect of debt financing (Jensen and Meckling 1976, Allen, Carletti, and Marquez 2015). Thus, the lesser extent of risk-taking by Japanese companies due to the governance structure is one of plausible causes for the volatility difference

However, we could not find the statistically significant dominance in both orders. The results are available from the authors upon request. 
between the U.S. and Japan.

\subsubsection{Allocative efficiency}

Another possible explanation is the difference in the speed of the resource reallocation from inefficient sectors to more efficient sectors. If the resource reallocation is smooth, the labor force, capital and other resources are quickly reallocated from unproductive sectors to productive sectors. If the production technology exhibits the decreasing returns to scale, the cross-section variation of productivity diminishes as a result of this resource reallocation (Bartelsman et al 2013). If we are allowed to think the profitability as a proxy for the productivity, we can interpret the smaller standard deviation in profitability indicates the higher speed of reallocation in Japan ceteris paribus, although this interpretation is contradictory to the existing evidence that the U.S. firms are quicker to reallocate resources (e.g., Allen et al 2018).

A twist that makes our interpretation complicated and interesting is that the cross-section variation is larger if an economy faces more frequent technology shocks that generate an additional productivity gap among companies and trigger a resource reallocation. Thus, in our context, a possible hypothesis is that the larger cross-section variation in the U.S. is due to the more frequent technology shocks that churn the industrial structure and trigger the resource reallocation.

\subsubsection{Cross-section variation versus time-series variation}

To see the relative importance of the two hypothetical mechanisms: risk-taking or allocative efficiency, we decomposed the variation of profitability of each country into the firm-level random effect, which is time-invariant and persistent for each company, and the idiosyncratic variation, which 
is both firm- and time-varying, by estimating the following random effect model with the matched sample for each country.

$$
\text { profitability }_{\mathrm{it}}=\beta_{0}+\beta_{t}+\mathrm{u}_{\mathrm{i}}+e_{i t} \text {, }
$$

where the dependent variable is the profitability measure of firm i in year t: ROA, or operating profit over total asset, $\beta_{0}$ is the constant, $\beta_{\mathrm{t}}(\mathrm{t}=2006,2007 \ldots .2015)$ is the year fixed effect to control for macroeconomic factors in each year, $u_{i}$ is the i.i.d. random effect of firm $i$ with mean zero, and $e_{i t}$ is the i.i.d. idiosyncratic shock for firm $\mathrm{i}$ in year $\mathrm{t}$ with mean zero, which is uncorrelated with $\mathrm{u}_{\mathrm{i}}$. What we are the most interested in is the relative importance of the variation driven by the firm heterogeneity, i.e., the standard error of $\mathrm{u}_{\mathrm{i}}$, which we denote $\sigma_{\mathrm{u}}$, and the variation driven by the timevarying idiosyncratic factor, i.e., the standard error of $\mathrm{e}_{\mathrm{it}}$, which we denote $\sigma_{\mathrm{e}}$. If the former has a larger impact on the U.S.-Japan difference, then the primary cause is the difference in the intensity of technology shock that triggers the resource reallocation. If the latter has a larger impact, the difference is more likely to be brought by the idiosyncratic factors, which is presumably associated with the risk-taking behavior by each firm. In the estimation, we use a matched panel data, which is constructed by the Mahalanobis nearest neighborhood matching by the information as of the beginning of the sample period 2005 .

The result is listed in Table 6. Both the firm-level random effect $\sigma_{\mathrm{u}}$, and the idiosyncratic variation $\sigma_{\mathrm{e}}$ are larger in the U.S., than in Japan. The third column in Table 6 shows the relative ratio of them. Both in ROA and the operating cashflow over asset, the ratio of the cross-section variation is larger in the U.S. This implies that the difference in the firm heterogeneity, or the productivity gap among companies is somewhat more important factor in the difference between these countries. 


\subsubsection{Difference in the risk-taking behavior}

Lastly, we calculate the firm-level risk-taking index, which is proposed by John, Litov, and Yeung (2008), with the matched sample. We calculate the index, which they call RISK1 of firm i, ${ }^{5}$ i.e.,

$$
\text { RISK1 }=\sqrt{\frac{1}{T-1} \sum_{t=1}^{T}\left(E_{i, c, t}-\frac{1}{T} \sum_{t=1}^{T} E_{i, c, t}\right)^{2}}
$$

where

$$
\mathrm{E}_{\mathrm{i}, \mathrm{c}, \mathrm{t}}=\text { profitability }_{i, c, t}-\frac{1}{N_{c, t}} \sum_{k=1}^{N_{c, i}} \text { profitability }_{i, c, t} \text {, }
$$

where $\mathrm{c}$ is the index of the country where firm $\mathrm{i}$ is located, $\mathrm{N}_{\mathrm{c}, \mathrm{t}}$ is the number of firms in country $\mathrm{c}$, profitability is a profitability measure, i.e., ROA or the ratio of operating cashflow over asset. We drop the firms whose available information is shorter than 5 years.

The average of RISK1 in each country with respect to each measure of profitability and the test result of the difference in means are listed in Table 7. The risk-taking measure of each profitable measure is about $3 \%$ on average in Japan, while it is $6 \%$ in the U.S. The difference in means is statistically significant at a $1 \%$ significance level. This result indicates that the difference in the risk-taking behavior is also a significant factor that brings the difference in the standard deviation in the standard deviation of profitability between these countries.

\section{Conclusion}

We have verified that the finding that the standard deviation and the median in the profitability of

\footnotetext{
${ }^{5}$ P. 1688 in John et al (2008).
} 
the U.S. listed companies is significantly larger than that of Japanese listed companies is still valid after controlling for the differences in the industry composition, equity size, and firm age between these countries. The matched panel-data analysis and the analysis of the existing risk-taking index shows that this difference in variation is brought not only by the difference in the idiosyncratic variations due to the risk-taking by each company, but also by the difference in the cross-section variation reflecting the churning shock. In light of the existing empirical studies that show a risktaker grows faster in the U.S. (John et al 2008) and Japan (Xu, 2015), for the purpose of boosting the firm growth, the reforms in corporate governance in Japan to reinforce the shareholders' right, such as the introductions of the Corporate Governance Code in 2015 or the Stewardship Code in 2014, are in the right direction. We keep our eyes on the consequence of these reforms.

\section{Reference}

Abadie, A., D. Drukker, J.L. Herr, and G.W. Imbens, 2004, "Implementing matching estimators for average treatment effects in Stata," The Stata Journal 4(3): 290-311.

Allen, F., E. Carletti, and Y. Grinstein, 2018, "International evidence on firm level decisions in response to the crisis: Shareholders vs. other stakeholders," Journal of the Japanese and International Economies 47: 3-16.

Allen, F., E. Carletti, and R. Marquez, 2015, "Stakeholder governance, competition, and firm value," Review of Finance 19: 1315-1346.

Arikawa, Y., K. Inoue, and T. Saito, 2017, “Corporate governance, employment laws, and corporate performance in Japan: an international perspective,” Department of Industrial Engineering and Economics Working Paper No. 2016-9, Tokyo Institute of Technology. 
Arikawa, Y., and H. Miyajima, 2007, "Relationship banking in post-bubble Japan: coexistence of soft- and hard-budget constraints," Ch.2, in Corporate Governance in Japan, Aoki, M., G. Jackson, and H. Miyajima,eds, Oxford University Press.

Arikawa, Y., H. Miyajima, and R. Ogawa, 2017, “Mega bank seiritsugo no kigyou-gin'koukan kankei” (firm-bank relationship after the emergence of mega banks) Ch.1 in Kigyo Touchi To Seihou Senryaku (Corporate Governance and Strategy for Growth), H. Miyajima, eds, (in Japanese), Toyo Keizai Shinpo Sha.

Bartelsman, E., J. Haltiwanger, and S. Scarpetta, 2013, “Cross-country differences in productivity: the role of allocation and selection," American Economic Review 103(1): 305-334.

Brown, G., and N. Kapadia, 2007, “Firm-specific risk and equity market development,” Journal of Financial Economics 84: 358-388.

Davidson, R., and J-Y. Duclos, 2000, "Statistical inference for stochastic dominance and for the measurement of poverty and inequality," Econometrica 68(6): 1435-1464.

Financial Service Agency, the Japanese Government, 2014, Stewardship Code, http://www.fsa.go.jp/en/refer/councils/stewardship/20140407.html.

Financial Service Agency, the Japanese Government, 2015, Corporate Governance Code, http://www.fsa.go.jp/en/refer/councils/corporategovernance/20150306-1.html.

Hirota, S., 2014, "The board of directors in stakeholder society," Ch.6, in Corporate Finance and Governance in Stakeholder Society, Routledge.

Jensen, M. C., and W. H. Meckling, 1976, “Theory of the firm: managerial behavior, agency costs and ownership structure," Journal of Financial Economics 3:305-360.

John, K., L. Litov, and B. Yeung, 2008, “Corporate governance and risk-taking,” Journal of Finance 
63(4): 1679-1728.

Ministry of Economy, Trade, and Industry, 2014, "Ito Review of Competitiveness and Incentives for Sustainable Growth-Building Favorable Relationships between Companies and InvestorsFinal Report" http://www.meti.go.jp/english/press/2014/pdf/0806 04b.pdf.

Xu, Peng, 2015, “Risk taking and firm growth,” RIETI Discussion Paper Series 15E061. 
Table 1 Industrial composition of listed companies

(Note) Two digit classification in NAICS 2012 except for the following: manufacturing is Sectors 31-33, retail trade is Sectors 44-45, transportation and warehousing are Sectors 48-49)

\begin{tabular}{|c|c|c|c|c|c|c|c|c|c|c|c|c|}
\hline & \multicolumn{4}{|l|}{2006} & \multicolumn{4}{|l|}{2010} & \multicolumn{4}{|l|}{2014} \\
\hline & \multicolumn{2}{|l|}{ Japan } & \multicolumn{2}{|l|}{ US } & \multicolumn{2}{|l|}{ Japan } & \multicolumn{2}{|c|}{ US } & \multicolumn{2}{|l|}{ Japan } & \multicolumn{2}{|c|}{ US } \\
\hline & \#firms & $(\%)$ & \#firms & $(\%)$ & \#firms & $(\%)$ & \#firms & $(\%)$ & \#firms & $(\%)$ & \#firms & $(\%)$ \\
\hline Agriculture, forestry, fishing and & 5 & $(0.2)$ & 4 & $(0.2)$ & 7 & $(0.2)$ & 5 & $(0.2)$ & 8 & $(0.3)$ & 7 & $(0.3)$ \\
\hline $\begin{array}{l}\text { Mining, quarrying, and oil and } \\
\text { gas extraction }\end{array}$ & 8 & $(0.3)$ & 113 & (4.6) & 9 & $(0.3)$ & 145 & (5.9) & 9 & $(0.3)$ & 180 & (7.2) \\
\hline Construction & 179 & $(5.9)$ & 31 & (1.3) & 145 & $(5.0)$ & 37 & $(1.5)$ & 148 & $(4.9)$ & 39 & (1.6) \\
\hline Manufacturing & 1,558 & $(51.7)$ & 1,245 & $(50.3)$ & 1,504 & $(52.2)$ & 1,205 & $(48.8)$ & 1,517 & $(50.5)$ & 1,157 & $(46.6)$ \\
\hline Wholesale trade & 271 & $(9.0)$ & 110 & (4.4) & 253 & $(8.8)$ & 102 & $(4.1)$ & 247 & $(8.2)$ & 100 & (4.0) \\
\hline Retail trade & 246 & $(8.2)$ & 136 & (5.5) & 231 & $(8.0)$ & 141 & (5.7) & 246 & $(8.2)$ & 142 & (5.7) \\
\hline Transportation and warehousing & 125 & $(4.1)$ & 80 & (3.2) & 116 & $(4.0)$ & 92 & $(3.7)$ & 120 & $(4.0)$ & 98 & (3.9) \\
\hline Information & 129 & (4.3) & 257 & (10.4) & 106 & $(3.7)$ & 218 & $(8.8)$ & 116 & $(3.9)$ & 233 & (9.4) \\
\hline Real estate and rental and leasing & 34 & $(1.1)$ & 16 & (0.6) & 32 & (1.1) & 27 & $(1.1)$ & 37 & $(1.2)$ & 20 & $(0.8)$ \\
\hline $\begin{array}{l}\text { Professional, scientific, and } \\
\text { technical services }\end{array}$ & 230 & (7.6) & 235 & $(9.5)$ & 246 & $(8.5)$ & 248 & $(10.0)$ & 279 & $(9.3)$ & 281 & (11.3) \\
\hline $\begin{array}{l}\text { Administrative, support, waste } \\
\text { management and remediation }\end{array}$ & 71 & (2.4) & 66 & (2.7) & 69 & (2.4) & 61 & $(2.5)$ & 90 & $(3.0)$ & 60 & (2.4) \\
\hline Educational services & 17 & $(0.6)$ & 13 & $(0.5)$ & 21 & $(0.7)$ & 19 & $(0.8)$ & 23 & $(0.8)$ & 18 & $(0.7)$ \\
\hline Health care and social assistance & 16 & $(0.5)$ & 62 & (2.5) & 18 & $(0.6)$ & 65 & (2.6) & 24 & $(0.8)$ & 48 & (1.9) \\
\hline Arts, entertainment, and & 30 & $(1.0)$ & 27 & (1.1) & 28 & $(1.0)$ & 29 & $(1.2)$ & 30 & (1.0) & 29 & (1.2) \\
\hline Accommodation and food & 77 & (2.6) & 61 & (2.5) & 77 & $(2.7)$ & 57 & (2.3) & 91 & (3.0) & 58 & $(2.3)$ \\
\hline $\begin{array}{l}\text { Other services (except public } \\
\text { administration) }\end{array}$ & 20 & (0.7) & 17 & (0.7) & 20 & $(0.7)$ & 19 & $(0.8)$ & 21 & $(0.7)$ & 13 & $(0.5)$ \\
\hline Total & 3,016 & $(100.0)$ & 2,473 & (100.0) & 2,882 & $(100.0)$ & 2,470 & (100.0) & 3,006 & (100.0) & 2,483 & \\
\hline
\end{tabular}


Table 2 Firm characteristics

(Note) Asset and equity are the book value evaluated at the current USD at the end of each accounting period. Leverage is the ratio of the total liability over the total asset. Firm age is the years since the incorporation. ROA is EBITDA/total asset (\%). Operating cashflow over asset is the ratio of operating cashflow over the total asset (\%).

\begin{tabular}{|c|c|c|c|c|c|c|c|c|}
\hline 2006 & $\mathrm{~N}$ & mean & sd & $\min$ & p10 & p50 & p90 & $\max$ \\
\hline asset (bil USD) & 3016 & 1.708 & 8.423 & 0.004 & 0.049 & 0.269 & 2.681 & 277.000 \\
\hline equity (b/v, bil USD) & 3016 & 0.656 & 3.006 & -0.014 & 0.020 & 0.119 & 1.170 & 101.000 \\
\hline firm age (years) & 3016 & 46 & 28 & 0 & 11 & 45 & 83 & 333 \\
\hline leverage & 3016 & 0.523 & 0.206 & 0.014 & 0.235 & 0.537 & 0.792 & 1.308 \\
\hline $\mathrm{ROA}(\%)$ & 3011 & 8.39 & 7.20 & -77.29 & 2.25 & 7.89 & 16.35 & 44.39 \\
\hline operating cf/asset (\%) & 3008 & 5.33 & 10.35 & -260.12 & 1.35 & 5.84 & 11.69 & 90.32 \\
\hline 2010 & $\mathrm{~N}$ & mean & sd & $\min$ & p10 & p50 & p90 & $\max$ \\
\hline asset (bil USD) & 2882 & 2.381 & 11.700 & 0.001 & 0.056 & 0.348 & 3.542 & 359.000 \\
\hline equity (b/v, bil USD) & 2882 & 0.978 & 4.565 & -0.084 & 0.023 & 0.156 & 1.680 & 131.000 \\
\hline firm age (years) & 2882 & 48 & 27 & 0 & 13 & 48 & 84 & 332 \\
\hline leverage & 2882 & 0.507 & 0.273 & 0.019 & 0.216 & 0.505 & 0.783 & 9.257 \\
\hline $\mathrm{ROA}(\%)$ & 2881 & 8.05 & 10.29 & -311.19 & 2.27 & 7.77 & 15.73 & 48.19 \\
\hline operating cf/asset (\%) & 2878 & 5.24 & 14.77 & -537.43 & 1.04 & 5.76 & 11.81 & 129.15 \\
\hline 2014 & $\mathrm{~N}$ & mean & sd & $\min$ & p10 & p50 & p90 & $\max$ \\
\hline asset (bil USD) & 3006 & 2.091 & 11.600 & 0.001 & 0.039 & 0.258 & 2.950 & 397.000 \\
\hline equity (b/v, bil USD) & 3006 & 0.923 & 4.444 & -0.008 & 0.018 & 0.131 & 1.484 & 147.000 \\
\hline firm age (years) & 3006 & 50 & 28 & 1 & 15 & 50 & 86 & 336 \\
\hline leverage & 3006 & 0.470 & 0.245 & 0.014 & 0.204 & 0.464 & 0.738 & 8.368 \\
\hline $\operatorname{ROA}(\%)$ & 3005 & 7.88 & 10.67 & -368.28 & 2.42 & 7.62 & 15.88 & 59.44 \\
\hline operating cf/asset (\%) & 3000 & 5.80 & 22.25 & -1144.57 & 2.08 & 6.25 & 12.04 & 42.77 \\
\hline
\end{tabular}


(b) U.S.

\begin{tabular}{lrrrrrrrr}
\hline 2006 & $\mathrm{N}$ & $\mathrm{m} e a n$ & $\mathrm{sd}$ & $\mathrm{min}$ & $\mathrm{p} 10$ & $\mathrm{p} 50$ & $\mathrm{p} 90$ & $\max$ \\
\hline asset (bil USD) & 2473 & 3.403 & 19.600 & 0.000 & 0.034 & 0.409 & 5.412 & 697.000 \\
equity (b/v, bil USD) & 2473 & 1.315 & 6.096 & -6.219 & 0.014 & 0.192 & 2.028 & 116.000 \\
firm age (years) & 2473 & 23 & 22 & 0 & 5 & 16 & 51 & 130 \\
leverage & 2473 & 0.476 & 0.319 & 0.000 & 0.158 & 0.450 & 0.779 & 8.288 \\
ROA (\%) & 2472 & 6.97 & 51.10 & -714.52 & -15.62 & 11.02 & 23.36 & 2055.41 \\
operating cf/asset (\%) & 2444 & 3.43 & 53.06 & -797.91 & -17.31 & 8.39 & 18.17 & 2055.41 \\
\hline 2010 & $\mathrm{N}$ & $\mathrm{mean}$ & $\mathrm{sd}$ & $\mathrm{min}$ & $\mathrm{p} 10$ & $\mathrm{p} 50$ & $\mathrm{p} 90$ & $\mathrm{max}$ \\
\hline asset (bil USD) & 2470 & 4.049 & 21.200 & 0.000 & 0.031 & 0.485 & 6.911 & 748.000 \\
equity (b/v, bil USD) & 2470 & 1.546 & 6.777 & -6.297 & 0.011 & 0.225 & 2.463 & 147.000 \\
firm age (years) & 2470 & 25 & 23 & 0 & 5 & 18 & 52 & 134 \\
leverage & 2470 & 0.613 & 2.329 & -0.173 & 0.173 & 0.469 & 0.824 & 91.879 \\
ROA (\%) & 2467 & 11.21 & 383.32 & -2930.72 & -10.52 & 11.00 & 23.96 & 18623.38 \\
operating cf/asset (\%) & 2455 & 5.94 & 386.69 & -2527.18 & -12.83 & 8.14 & 19.10 & 18623.38 \\
\hline 2014 & $\mathrm{N}$ & $\mathrm{mean}$ & $\mathrm{sd}$ & $\mathrm{min}$ & $\mathrm{p} 10$ & $\mathrm{p} 50$ & $\mathrm{p} 90$ & $\mathrm{max}$ \\
\hline asset (bil USD) & 2483 & 5.087 & 22.100 & 0.001 & 0.038 & 0.630 & 8.705 & 655.000 \\
firm age (years) & 2483 & 26 & 23 & 0 & 6 & 19 & 53 & 138 \\
equity (b/v, bil USD) & 2483 & 1.822 & 7.975 & -12.600 & 0.013 & 0.265 & 3.147 & 174.000 \\
leverage & 2483 & 0.531 & 0.339 & -0.606 & 0.172 & 0.508 & 0.866 & 6.679 \\
ROA (\%) & 2482 & 12.59 & 455.68 & -805.59 & -23.28 & 10.04 & 21.85 & 22631.04 \\
operating cf/asset (\%) & 2467 & -0.38 & 36.05 & -838.40 & -27.24 & 7.37 & 17.11 & 119.55 \\
\hline
\end{tabular}


Table 3 Comparison of profitability with the unmatched data

(Note) $* * *, * *$, and * indicate that the difference between Japan and US is statistically significant at the $1 \%, 5 \%$, and $10 \%$ level, respectively. The test statistics are t-statistics under the variable variance assumption for mean, the Wilcoxon rank-sum test for median, and the variance ratio test for s.d..

(a) ROA (EBITDA / total asset)

\begin{tabular}{|c|c|c|c|c|c|c|c|c|c|}
\hline & \multicolumn{3}{|l|}{ Mean } & \multicolumn{3}{|l|}{ Median } & \multicolumn{3}{|l|}{ S.D. } \\
\hline & Japan & US & & Japan & US & & Japan & US & \\
\hline 2005 & 8.5 & 8.5 & & 7.9 & 11.2 & $* * *$ & 6.5 & 40.0 & $* * *$ \\
\hline 2006 & 8.4 & 7.0 & & 7.9 & 11.0 & $* * *$ & 7.2 & 51.1 & $* * *$ \\
\hline 2007 & 8.4 & 6.6 & & 8.3 & 10.9 & $* * *$ & 10.0 & 58.7 & $* * *$ \\
\hline 2008 & 6.9 & -1.5 & & 6.9 & 10.9 & $* * *$ & 10.0 & 269.5 & $* * *$ \\
\hline 2009 & 6.3 & -0.3 & $* * *$ & 6.5 & 9.5 & $* * *$ & 9.0 & 114.6 & $* * *$ \\
\hline 2010 & 8.0 & 11.2 & & 7.8 & 11.0 & $* * *$ & 10.3 & 383.3 & $* * *$ \\
\hline 2011 & 8.0 & 12.3 & & 7.7 & 11.3 & $* * *$ & 8.9 & 401.2 & $* * *$ \\
\hline 2012 & 7.5 & 13.7 & & 7.3 & 10.8 & $* * *$ & 13.4 & 399.3 & $* * *$ \\
\hline 2013 & 8.1 & 12.2 & & 7.7 & 10.4 & $* * *$ & 8.1 & 387.2 & $* * *$ \\
\hline 2014 & 7.9 & 12.6 & & 7.6 & 10.0 & $* * *$ & 10.7 & 455.7 & $* * *$ \\
\hline
\end{tabular}

(b) Operating cash flow / total asset

\begin{tabular}{|c|c|c|c|c|c|c|c|c|c|}
\hline & \multicolumn{3}{|l|}{ Mean } & \multicolumn{3}{|l|}{ Median } & \multicolumn{3}{|l|}{ S.D. } \\
\hline & Japan & US & & Japan & US & & Japan & US & \\
\hline 2005 & 5.8 & 4.6 & & 6.0 & 8.4 & $* * *$ & 7.1 & 36.0 & $* * *$ \\
\hline 2006 & 5.3 & 3.4 & $*$ & 5.8 & 8.4 & $* * *$ & 10.4 & 53.1 & $* * *$ \\
\hline 2007 & 4.8 & 3.8 & & 5.9 & 8.1 & $* * *$ & 13.3 & 57.2 & $* * *$ \\
\hline 2008 & 2.9 & -1.8 & $*$ & 4.6 & 8.0 & $* * *$ & 12.9 & 140.6 & $* * *$ \\
\hline 2009 & 3.6 & -7.2 & $* * *$ & 4.8 & 6.8 & $* * *$ & 11.7 & 190.0 & $* * *$ \\
\hline 2010 & 5.2 & 5.9 & & 5.8 & 8.1 & $* * *$ & 14.8 & 386.7 & $* * *$ \\
\hline 2011 & 5.4 & 8.3 & & 5.7 & 8.3 & $* * *$ & 10.1 & 404.4 & $* * *$ \\
\hline 2012 & 4.9 & 9.7 & & 5.9 & 8.0 & $* * *$ & 39.7 & 400.1 & $* * *$ \\
\hline 2013 & 6.2 & 0.8 & $* * *$ & 6.3 & 7.7 & $* * *$ & 7.4 & 34.2 & $* * *$ \\
\hline 2014 & 5.8 & -0.4 & $* * *$ & 6.3 & 7.4 & $* * *$ & 22.2 & 36.0 & $* * *$ \\
\hline
\end{tabular}


Table 4 Industry composition of the matched sample (two digit classification in NAICS 2012 except for the following: manufacturing is Sectors 31-33, retail trade is Sectors 44-45, transportation and warehousing are Sectors 48-49)

\begin{tabular}{|c|c|c|c|c|c|c|}
\hline & $\begin{array}{r}2006 \\
\text { \#firms }\end{array}$ & $(\%)$ & $\begin{array}{r}2010 \\
\text { \#firms }\end{array}$ & $(\%)$ & $\begin{array}{r}2014 \\
\text { \#firms }\end{array}$ & $(\%)$ \\
\hline $\begin{array}{l}\text { Agriculture, forestry, } \\
\text { fishing and hunting }\end{array}$ & 5 & $(0.2)$ & 7 & $(0.3)$ & 7 & $(0.3)$ \\
\hline $\begin{array}{l}\text { Mining, quarrying, and } \\
\text { oil and gas extraction }\end{array}$ & 6 & $(0.2)$ & 9 & $(0.3)$ & 9 & $(0.3)$ \\
\hline Construction & 143 & $(5.4)$ & 143 & $(5.1)$ & 142 & (5.4) \\
\hline Manufacturing & 1,430 & $(54.4)$ & 1,472 & $(52.6)$ & 1,381 & (52.9) \\
\hline Wholesale trade & 241 & $(9.2)$ & 251 & $(9.0)$ & 232 & (8.9) \\
\hline Retail trade & 195 & (7.4) & 225 & $(8.0)$ & 203 & (7.8) \\
\hline $\begin{array}{l}\text { Transportation and } \\
\text { warehousing }\end{array}$ & 115 & $(4.4)$ & 114 & $(4.1)$ & 111 & $(4.3)$ \\
\hline Information & 101 & $(3.8)$ & 102 & (3.6) & 87 & (3.3) \\
\hline $\begin{array}{l}\text { Real estate, rental and } \\
\text { leasing }\end{array}$ & 26 & $(1.0)$ & 30 & $(1.1)$ & 24 & $(0.9)$ \\
\hline $\begin{array}{l}\text { Professional, scientific, } \\
\text { and technical services }\end{array}$ & 179 & $(6.8)$ & 221 & $(7.9)$ & 211 & $(8.1)$ \\
\hline $\begin{array}{l}\text { Administrative, } \\
\text { support, waste } \\
\text { management and } \\
\text { remediation services }\end{array}$ & 53 & $(2.0)$ & 63 & $(2.3)$ & 59 & $(2.3)$ \\
\hline Educational services & 15 & $(0.6)$ & 20 & $(0.7)$ & 16 & $(0.6)$ \\
\hline $\begin{array}{l}\text { Health care and social } \\
\text { assistance }\end{array}$ & 15 & $(0.6)$ & 18 & $(0.6)$ & 15 & $(0.6)$ \\
\hline $\begin{array}{l}\text { Arts, entertainment, } \\
\text { and recreation }\end{array}$ & 24 & $(0.9)$ & 27 & (1.0) & 24 & $(0.9)$ \\
\hline $\begin{array}{l}\text { Accommodation and } \\
\text { food services }\end{array}$ & 64 & $(2.4)$ & 77 & $(2.8)$ & 73 & $(2.8)$ \\
\hline $\begin{array}{l}\text { Other services (except } \\
\text { public administration) }\end{array}$ & 18 & $(0.7)$ & 20 & $(0.7)$ & 16 & $(0.6)$ \\
\hline Total & 2,630 & $(100.0)$ & 2,799 & $(100.0)$ & 2,610 & $(100.0)$ \\
\hline
\end{tabular}


Table 5 Comparison of profitability with the matched dataset

(Note) $* * *, * *$, and * indicate that the difference between Japan and US is statistically significant at the $1 \%, 5 \%$, and $10 \%$ level, respectively. The test statistics are t-statistics under the variable variance assumption for mean, the Wilcoxon rank-sum test for median, and the variance ratio test for s.d..

(a) ROA (EBITDA / total asset, \%)

\begin{tabular}{|c|c|c|c|c|c|c|c|c|c|}
\hline & \multicolumn{3}{|l|}{ Mean } & \multicolumn{3}{|l|}{ Median } & \multicolumn{3}{|l|}{ S.D. } \\
\hline & Japan & US & & Japan & US & & Japan & US & \\
\hline 2005 & 8.6 & 11.6 & $* * *$ & 8.0 & 12.1 & $* * *$ & 5.2 & 11.6 & $* * *$ \\
\hline 2006 & 8.7 & 10.6 & $* * *$ & 8.1 & 12.4 & $* * *$ & 5.6 & 13.6 & $* * *$ \\
\hline 2007 & 8.9 & 8.6 & & 8.4 & 11.1 & $* * *$ & 6.1 & 15.7 & $* * *$ \\
\hline 2008 & 7.4 & 7.3 & & 7.0 & 10.7 & $* * *$ & 6.4 & 21.2 & $* * *$ \\
\hline 2009 & 6.6 & 6.0 & $* *$ & 6.5 & 7.8 & $* * *$ & 6.4 & 16.1 & $* * *$ \\
\hline 2010 & 8.4 & 9.0 & $* *$ & 7.8 & 10.8 & $* * *$ & 5.6 & 15.0 & $* * *$ \\
\hline 2011 & 8.2 & 8.6 & & 7.7 & 10.6 & $* * *$ & 5.4 & 15.9 & $* * *$ \\
\hline 2012 & 7.8 & 8.3 & & 7.2 & 11.0 & $* * *$ & 5.4 & 16.0 & $* * *$ \\
\hline 2013 & 8.1 & 8.1 & & 7.6 & 11.3 & $* * *$ & 5.3 & 15.9 & $* * *$ \\
\hline 2014 & 7.9 & 7.6 & & 7.4 & 10.7 & $* * *$ & 5.2 & 15.2 & $* * *$ \\
\hline
\end{tabular}

(b) Operating cash flow / total asset (\%)

\begin{tabular}{|c|c|c|c|c|c|c|c|c|c|}
\hline & \multicolumn{3}{|l|}{ Mean } & \multicolumn{3}{|l|}{ Median } & \multicolumn{3}{|l|}{ S.D. } \\
\hline & Japan & US & & Japan & US & & Japan & US & \\
\hline 2005 & 6.1 & 8.3 & $* * *$ & 6.0 & 9.3 & $* * *$ & 5.5 & 10.8 & $* * *$ \\
\hline 2006 & 6.0 & 7.8 & $* * *$ & 5.9 & 9.3 & $* * *$ & 6.3 & 12.7 & $* * *$ \\
\hline 2007 & 5.8 & 6.4 & $* *$ & 6.0 & 7.9 & $* * *$ & 8.3 & 13.9 & $* * *$ \\
\hline 2008 & 4.0 & 4.6 & $*$ & 4.8 & 7.8 & $* * *$ & 7.4 & 19.6 & $* * *$ \\
\hline 2009 & 4.3 & 4.0 & & 4.9 & 6.6 & $* * *$ & 7.7 & 16.3 & $* * *$ \\
\hline 2010 & 5.8 & 6.0 & & 5.7 & 7.8 & $* * *$ & 6.5 & 15.0 & $* * *$ \\
\hline 2011 & 5.8 & 5.8 & & 5.7 & 8.2 & $* * *$ & 5.0 & 15.0 & $* * *$ \\
\hline 2012 & 5.9 & 5.4 & & 5.9 & 8.2 & $* * *$ & 5.5 & 15.7 & $* * *$ \\
\hline 2013 & 6.4 & 5.2 & $* * *$ & 6.2 & 9.0 & $* * *$ & 4.6 & 16.6 & $* * *$ \\
\hline 2014 & 6.3 & 4.5 & $* * *$ & 6.1 & 7.6 & $* * *$ & 4.7 & 14.5 & $* * *$ \\
\hline
\end{tabular}


Table 6 Cross-section variation vs. time-series variation

(Note) The estimated components of standard errors are listed. The model is the firm-level random effect model with the year dummies. The dataset is an unbalanced firm-year panel data after the Mahalanobis nearestneighborhood matching with respect to the book value of equity and the years since incorporation as of 2005 within the same industry class.

\begin{tabular}{lcccccc}
\hline $\begin{array}{l}\text { Dependent } \\
\text { variable }\end{array}$ & $\begin{array}{c}\text { Firm-level } \\
\text { random effect } \sigma_{\mathrm{u}}\end{array}$ & $\begin{array}{c}\text { Idiosyncratic } \\
\text { variation } \sigma_{\mathrm{e}}\end{array}$ & $\sigma_{\mathrm{u}} /\left(\sigma_{\mathrm{u}}+\sigma_{\mathrm{e}}\right)$ & \#firms & $\mathrm{N}$ \\
\hline ROA & Japan & 0.043 & 0.034 & 0.613 & 2515 & 23405 \\
& US & 0.115 & 0.082 & 0.663 & 2515 & 23993 \\
\hline \multirow{2}{*}{ Op. CF/asset } & Japan & 0.036 & 0.051 & 0.326 & 2512 & 23965 \\
& US & 0.102 & 0.089 & 0.567 & 2515 & 23200 \\
\hline
\end{tabular}

Table 7 Comparison of the John-Litov-Yeung risk-taking index

(Note) The sample average of the risk-taking index, based on the company risk-taking proxy (RISK1) by JohnLitov-Yeung (2008, P1688) in each country. The sample is the matched sample by the Mahalanobis nearestneighborhood matching with respect to the book value of equity and the years since incorporation as of 2005 within the same industry class. T-stats are the ones under the assumption of different variances.

\begin{tabular}{lrrrrr}
\hline & Japan & US & t-stats & p-values & N \\
\hline ROA (\%) & 2.842 & 6.146 & -25.6 & $(0.000)$ & 2515 \\
Operating CF/asset (\%) & 3.268 & 6.300 & -17.8 & $(0.000)$ & 2510 \\
\hline
\end{tabular}


Figure 1 Comparison of the profitability (Unmatched sample)

(a) $\mathrm{ROA}$

(1) MEAN

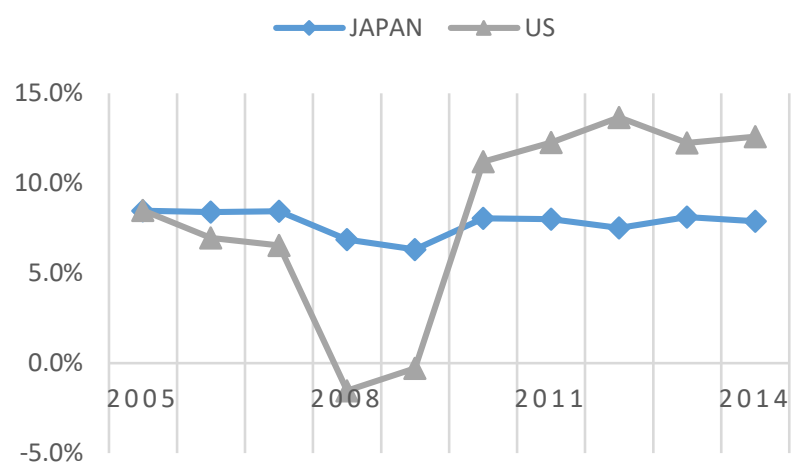

(3) STANDARD DEVIATION

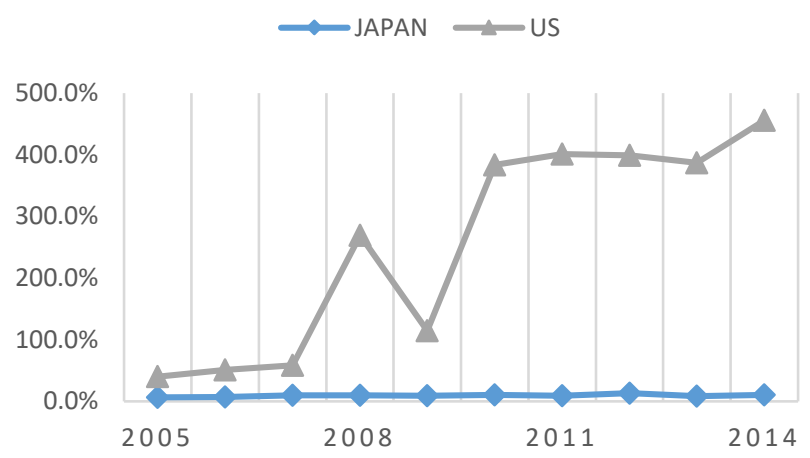

(2) MEDIAN

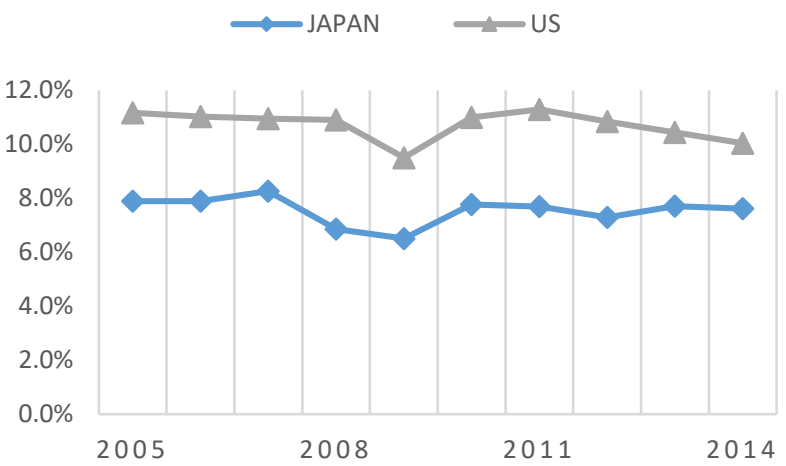


(b) Operating cash flow / asset

(1) MEAN

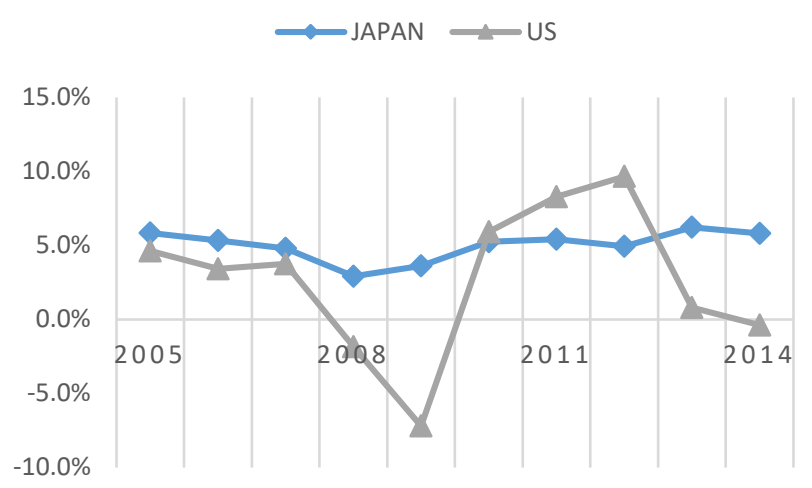

(3) STANDARD DEVIATION

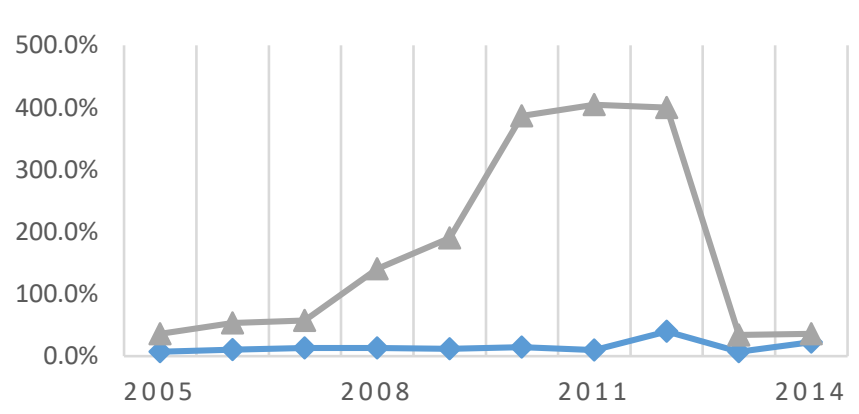


Figure 2 Firm characteristics before and after matching

(Note) The estimated density functions after dropping the outliers in the top 5\% and bottom $5 \%$ by the kernel estimation (Epanechnikov) is plotted.

(a) Firm age in 2010
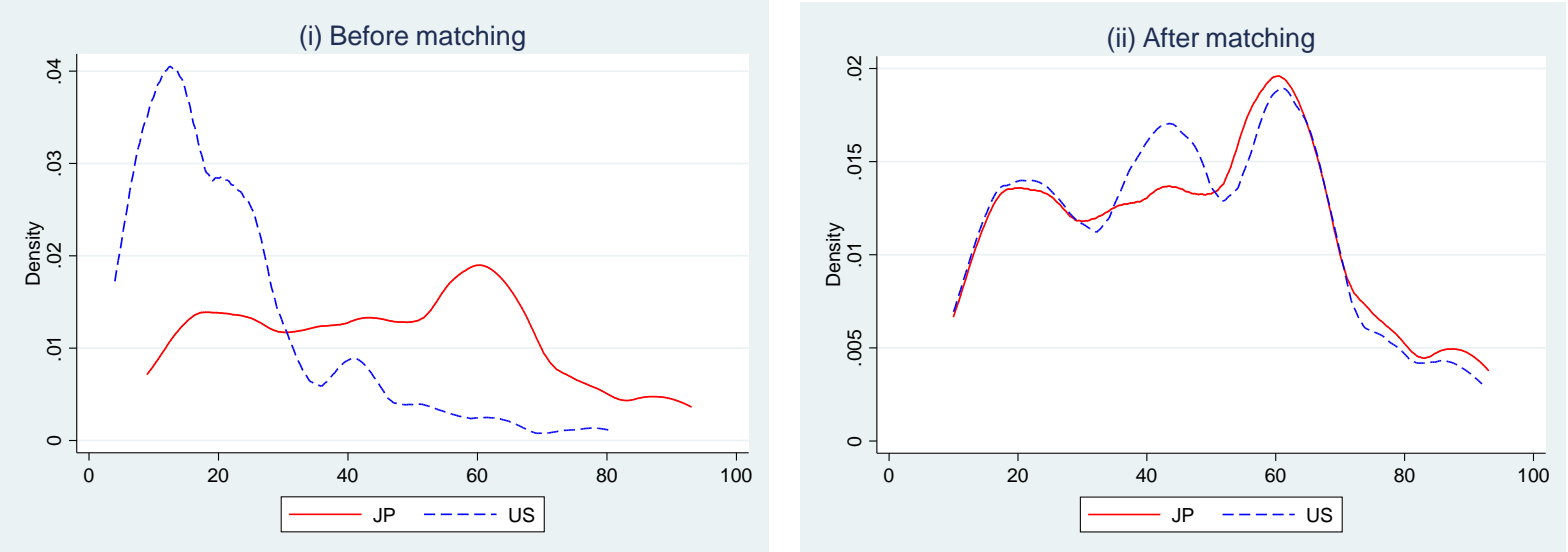

(b) Equity size in 2010
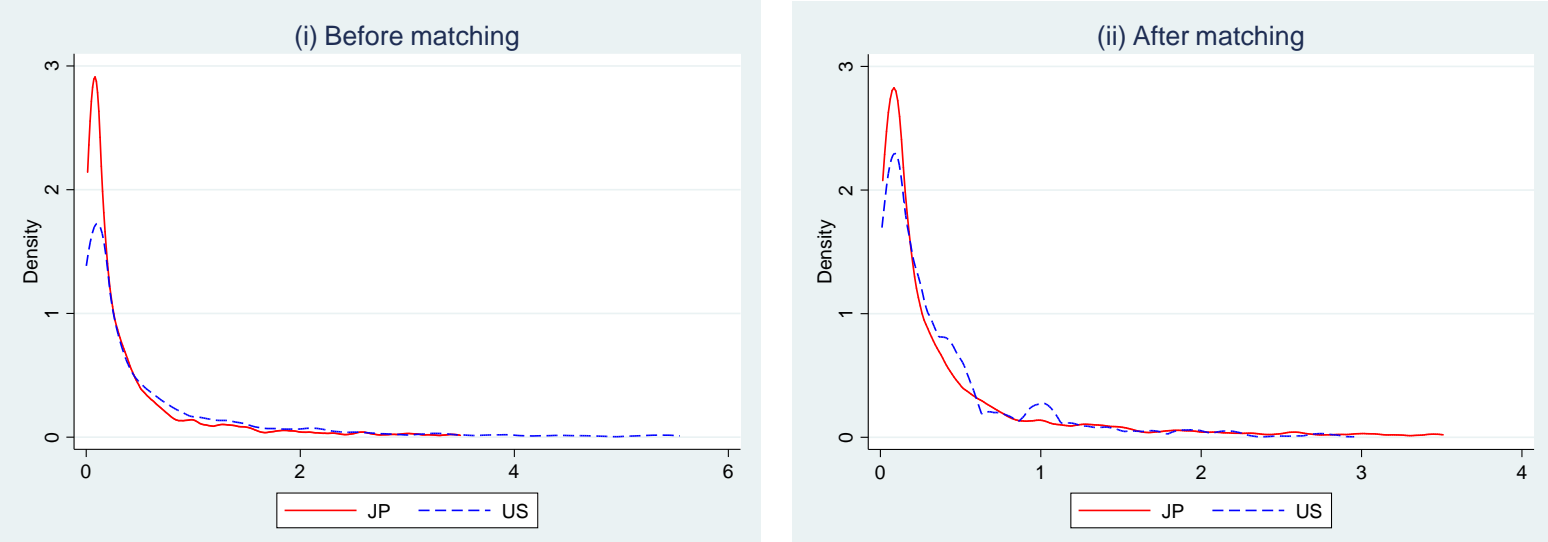
Figure 3 Comparison of the profitability (matched sample)

(a) $\mathrm{ROA}$

(1) MEAN

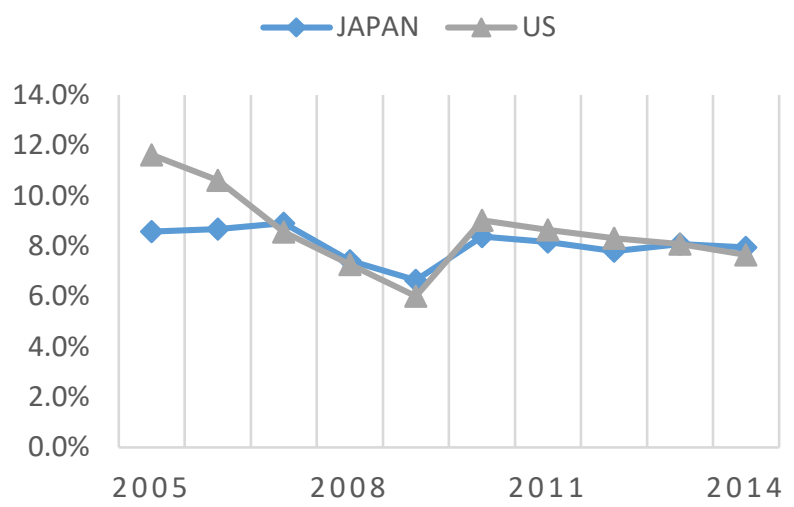

(3) STANDARD DEVIATION

$\leadsto$ JAPAN $\rightarrow$ US

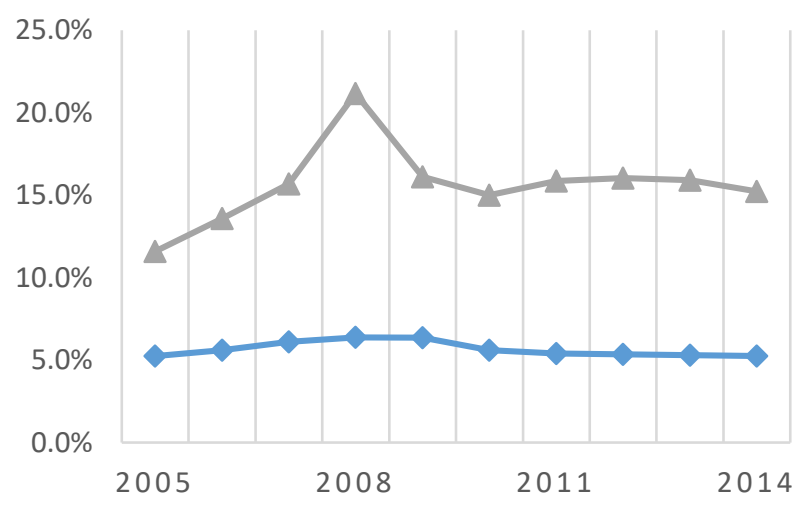

(2) MEDIAN

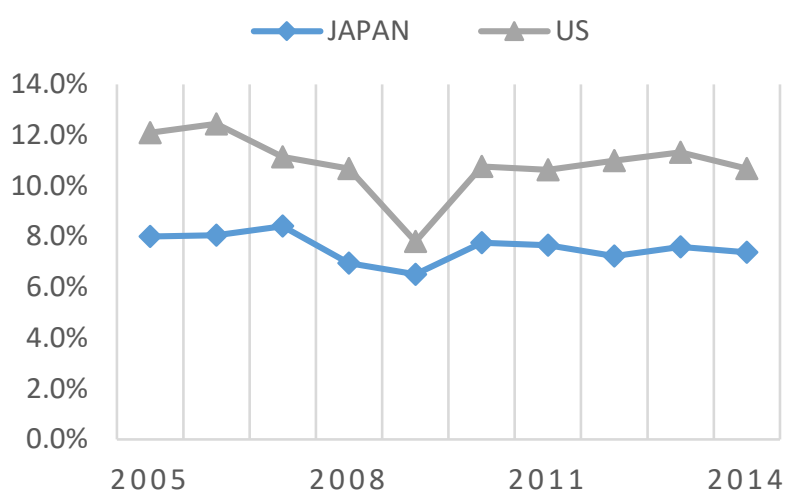


(b) Operating cash flow / asset

(1) MEAN

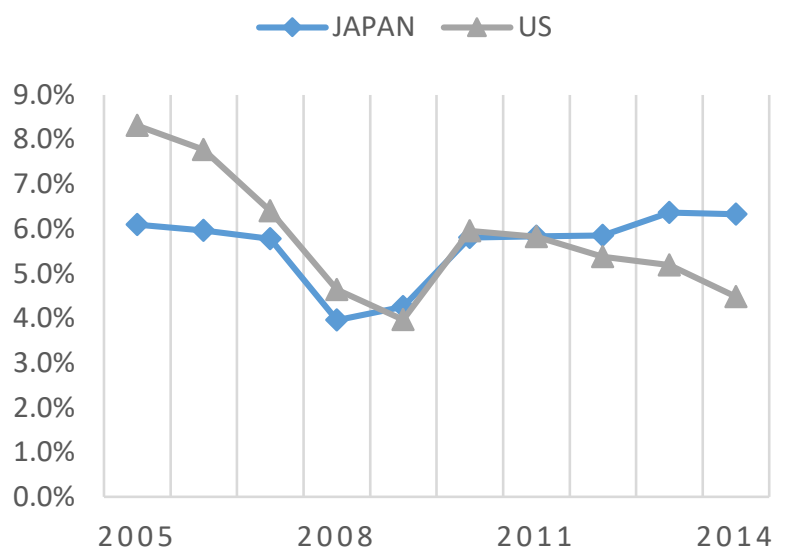

(3) STANDARD DEVIATION

$$
\leadsto \text { —JAPAN } \longrightarrow \text { US }
$$

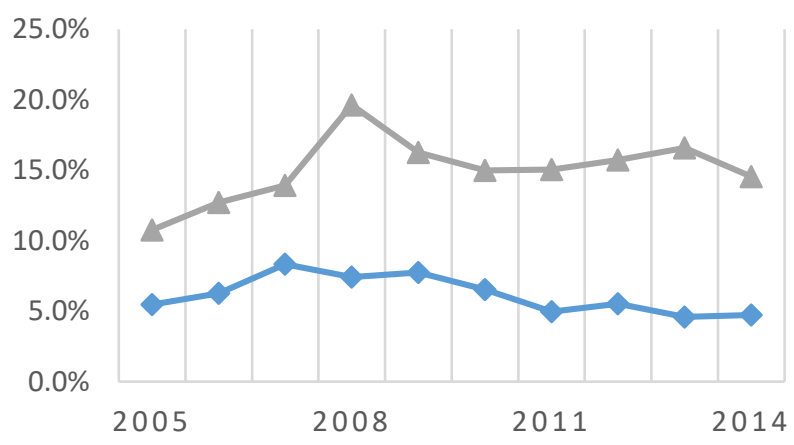

(2) MEDIAN

$\leadsto$ JAPAN $\leftarrow$ US

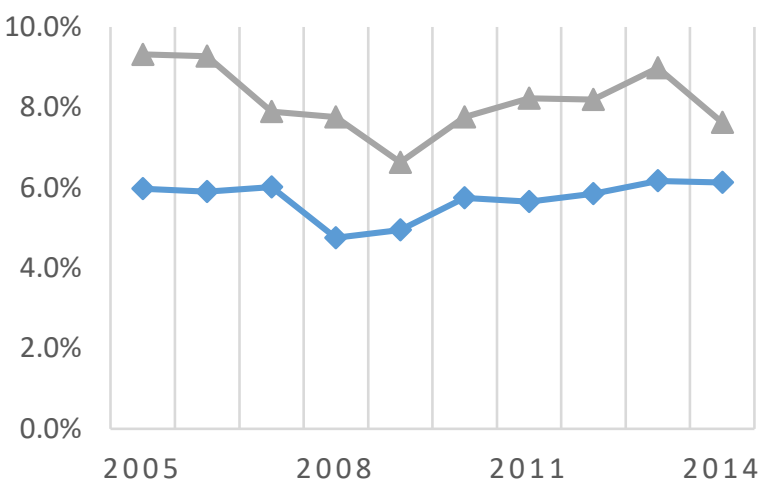


Figure 4 Estimated density of profitability (matched sample)

(Note) The estimated density functions after dropping the outliers in the top $5 \%$ and bottom $5 \%$ by the kernel estimation (Epanechnikov) is plotted.

(a) $\mathrm{ROA}$
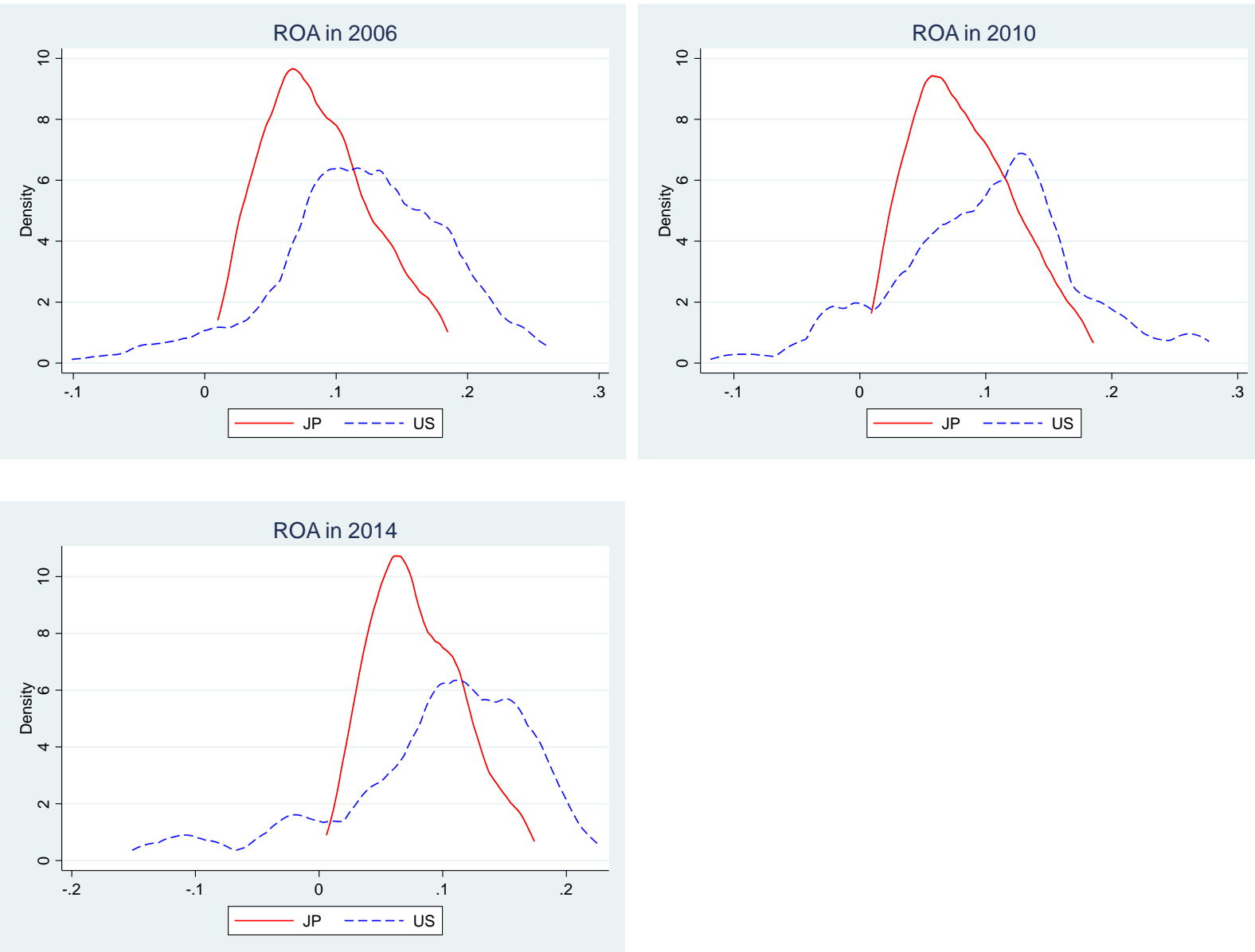
(b) Operating cash flow / asset
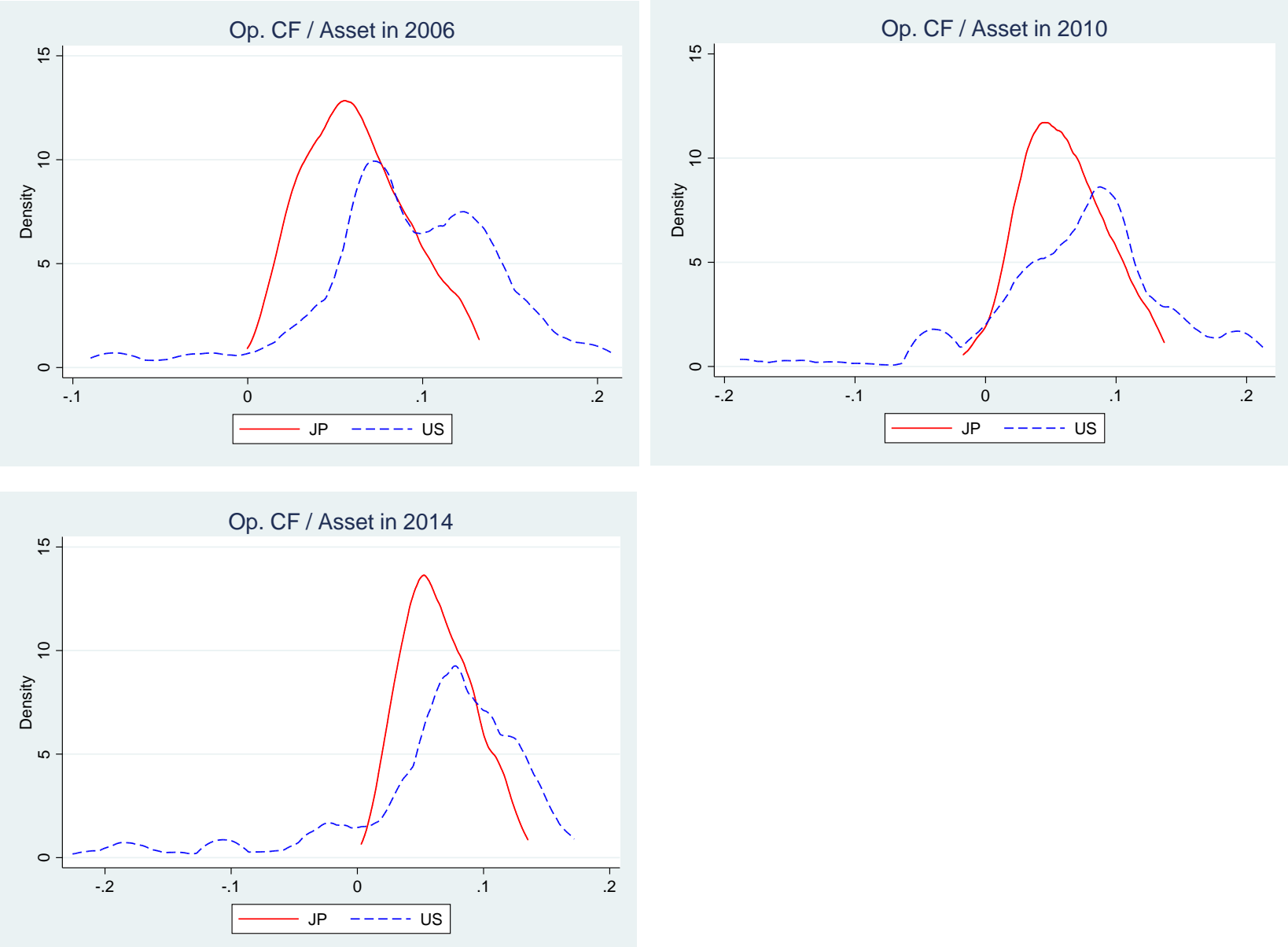